\title{
Effect of flaxseed physical form on digestibility of lactation diets fed to Holstein steers
}

\author{
J. W. Schroeder, ${ }^{* 1}$ M. L. Bauer, ${ }^{*}$ and N. R. Bork† \\ *Department of Animal Sciences, North Dakota State University, Fargo 58108 \\ †Standard Nutrition Services, Luverne, MN 56156
}

\section{ABSTRACT}

Four multicannulated (rumen, duodenum, and ileum) Holstein steers $(459.7 \pm 46.4 \mathrm{~kg}$ of initial body weight) were used in a $4 \times 4$ Latin square design to determine the effect of flaxseed processing method on ruminal fermentation and digestibility. Treatments were based on inclusion of (1) 7.5\% linseed meal (control), (2) 10\% whole flaxseed, (3) 10\% rolled flaxseed, or (4) $10 \%$ ground flaxseed on a dry matter (DM) basis, and were formulated to mimic typical high-producing dairy cow lactation diets. The control diet contained linseed meal in a proportion to provide crude protein $(\mathrm{CP})$ equal to the amount of $\mathrm{CP}$ contributed by the flaxseed in the other treatments. Diets were fed for ad libitum intake and contained $30 \%$ corn silage, $17 \%$ chopped alfalfa hay, $6 \%$ sugar beet pulp, and $47 \%$ concentrate (comprising ground corn, supplemental protein, trace minerals and vitamins, and either flaxseed or linseed meal (DM basis). Diets were formulated to contain 17\% CP, $34 \%$ neutral detergent fiber, $21 \%$ acid detergent fiber, and $4 \%$ fatty acid (DM basis). Periods were $14 \mathrm{~d}$ long and consisted of $7 \mathrm{~d}$ of adaptation and $7 \mathrm{~d}$ of sample collection. Dry matter intake (as a \% of body weight) was similar $(2.41 \pm 0.17)$ for all treatments. The inclusion of flaxseed, regardless of processing method, tended to decrease total-tract organic matter digestibility relative to the linseed control, but no differences in CP intake, duodenal CP flow (bacterial, apparent feed, or total), ileal CP flow, fecal CP output, microbial efficiency, or $\mathrm{CP}$ digestibility (apparent ruminal, true ruminal, small intestine, large intestine, or total tract) were observed between treatments. Method of processing did not alter ruminal $\mathrm{pH}$, ammonia, or volatile fatty acids production. The ground flaxseed treatment had the fastest rate of in situ DM degradation $(11.25 \% / \mathrm{h})$, followed by the control $(7.46 \% / \mathrm{h})$, rolled flaxseed $(4.53 \% / \mathrm{h})$, and whole flaxseed $(0.57 \% / \mathrm{h})$ treatments. Degradability of $\mathrm{CP}$ and fat followed the same pattern as DM degradability for processed flaxseed. In situ degradation rates

Received January 6, 2014.

Accepted May 18, 2014.

${ }^{1}$ Corresponding author: jw.schroeder@ndsu.edu of alfalfa hay neutral detergent fiber and acid detergent fiber tended to be fastest for the ground flaxseed treatment. Taken together, the digestibility, fermentation, and in situ data indicate that rolling and grinding are both acceptable methods of processing flaxseed. The in situ data strongly support the need for processing flaxseed before inclusion in lactation diets.

Key words: dairy steer, digestibility, flaxseed, physical form

\section{INTRODUCTION}

Flaxseed can be used as a source of supplemental fat and protein for dairy cows (Mustafa et al., 2003). Nonetheless, supplementation of nonprotected fat in excess of $7 \%$ of dietary DM can decrease DMI and reduce digestibility in ruminants (Merchen, 1988; Doreau et al., 1991; Jenkins, 1993). Lipids can reduce fiber digestibility but the degree depends on the type and nature of the lipid (Ward et al., 2002). The reduction in DMI is associated with changes in ruminal fermentation, gut motility, palatability, release of gut hormones, and the oxidation of fat in the liver (Allen, 2000). Processing oil seeds increases ruminally unprotected PUFA, which can have detrimental effects on ruminal fermentation, including altering the microbial population or hindering microbial fiber digestion (Palmquist and Jenkins, 1980; Moore et al., 1986); however, processing methods such as rolling or grinding also generally increase the availability of nutrients to the animal. Gonthier et al. (2004) concluded that flaxseed supplementation $(12.6 \%$ of DM) improved total-tract digestibility with no detrimental effects on rumen function. Those authors also concluded that micronization increased RUP for flaxseed. Previous studies recommend the processing of flaxseed in beef finishing diets (Maddock et al., 2006) and lactating dairy cow diets (da Silva et al., 2007) compared with whole flaxseed but have not measured the effects of processing on digestion. Therefore, the objective of this study was to evaluate the effects of physical form of flaxseed on the site and extent of digestion, ruminal fermentation, and in situ degradation. Our focus was to assess relative differences of processing and method from altering the physical form of flaxseed. 


\section{MATERIALS AND METHODS}

\section{Animals and Diets}

All procedures were approved by the North Dakota State University (NDSU) Animal Care and Use Committee. Four Holstein steers $(459.7 \pm 46.4 \mathrm{~kg}$ of initial BW) with ruminal, duodenal, and ileal cannulas were used in a $4 \times 4$ Latin square design to determine the effect of flaxseed processing (whole, rolled, or ground) on ruminal fermentation and digestibility of nutrients. Steers were housed in individual pens $(3.0 \times 3.7 \mathrm{~m})$ at the NDSU Animal Nutrition and Physiology Center (Fargo). During the sample collection periods, steers were kept in individual metabolism stalls $(1.0 \times 2.2$ $\mathrm{m})$. Steers were fed completely mixed diets at 0700 and $1900 \mathrm{~h}$ daily and were allowed unlimited access to water. Diets were offered for ad libitum intake to ensure an approximate daily $5 \%$ rate of feed refusals.

All diets (Table 1) were formulated to meet NRC (2001) requirements for a lactating dairy cow. Steers were fed basal diets of $47 \%$ concentrate, $30 \%$ corn silage, $17 \%$ alfalfa hay, and $6 \%$ beet pulp shreds (DM basis). Alfalfa hay was chopped in a tub-grinder (HayBuster, model H1100 Tilt, DuraTech Industries International Inc., Jamestown, ND) with a 3.8-cm screen. Corn silage and alfalfa hay used for the study were from the same harvest. The concentrate portion of the diets containing the flaxseed or linseed meal was mixed before the initiation of the study by the NDSU Northern Crops Institute Feed Mill (Fargo, ND). Dietary treatments included (1) 7.5\% linseed meal (control), (2) 10\% whole flaxseed, (3) 10\% rolled flaxseed, or (4) $10 \%$ ground flaxseed. The control diet contained solvent-extracted linseed meal (Cargill, West Fargo, ND) at proportions equal to the amount of protein contributed by the flaxseed in the other treatments. The rolled flaxseed was processed using a roller-grinder (2-pair stacked rollers, $23 \times 30.5 \mathrm{~cm}$, top pair $=0.42$ corrugations $/ \mathrm{cm}$, bottom pair $=0.84$ corrugations $/ \mathrm{cm}$; differential drive reduction of 1.5:1, fast to slow; motor size $=25 \mathrm{hp}$; model K, Roskamp Champion, Waterloo, IA). The ground flaxseed was processed using a hammermill $(96.5 \mathrm{~cm}$ diameter, split-screen design, down-swing side $=4.8$ $\mathrm{mm}$ screen hole, up-swing side $=5.6-\mathrm{mm}$ screen hole; motor size $=50 \mathrm{hp}$; model E-38095 TF, Bliss Industries, Ponca City, OK). Chromic oxide was included in the diets as an external marker from d 4 to 14 at $0.25 \%$ of the DM to determine digesta flows at the duodenum. Chromic oxide was premixed into the concentrate by using a Hobart mixer (model H-600, Hobart Manufacturing Co., Troy, $\mathrm{OH})$.

Diets were mixed in advance using a Davis paddle mixer (model S-20, H. C. Davis Sons Mfg. Co. Inc.,
Bonner Springs, KS) in sufficient quantities to last 3 to $4 \mathrm{~d}$. The total mixed diets were stored in barrels in a walk-in freezer $\left(-20^{\circ} \mathrm{C}\right)$, with each day's rations moved to a walk-in cooler $\left(4^{\circ} \mathrm{C}\right)$ for $12 \mathrm{~h}$ before feeding twice daily at 0700 and 1900 h. Diet intakes were recorded and amounts were adjusted daily for fluctuations in DMI to include $5 \%$ daily refusal.

\section{Sample and Data Collection}

Each experimental period was $14 \mathrm{~d}$ long including 7 $\mathrm{d}$ for adaptation to the diet and $7 \mathrm{~d}$ for sample collection. For each animal, orts were collected on d 8 to 14, weighed, composited, and mixed by hand. Samples of duodenal (200 g) and ileal (100 g) chyme were collected on $\mathrm{d} 11$ to 13 in a manner to achieve a sampling point in time of every other hour between the feedings (0700 and 1900 h). Samples were composited within steer and period for the experiment. Fecal trays were placed behind the steers for total fecal collection from d 10 through 14. Fecal output was weighed and subsampled (10\% of wet weight), and composited across days within steer and stored at $-20^{\circ} \mathrm{C}$. Composite samples were mixed in a rotary mixer (model H-600, Hobart Manufacturing Co.) and subsampled. Fecal samples were dried in a forced-air oven for $48 \mathrm{~h}\left(50^{\circ} \mathrm{C}\right.$; model SB-350, Grieve Corp., Round Lake, IL). Chyme samples were freezedried and stored at $-20^{\circ} \mathrm{C}$.

On d 14, ruminal fluid samples were collected at -2 , $0,2,4,6,8,10$, and $12 \mathrm{~h}$ relative to the morning feeding. After the collection at $-2 \mathrm{~h}$, the rumen was dosed with $200 \mathrm{~mL}$ of a CoEDTA solution $(20 \mathrm{~g}$ of $\mathrm{Co} / \mathrm{L})$ via a catheter-tipped, $50-\mathrm{mL}$ syringe with a tube attached, to determine the ruminal liquid dilution rate (Uden et al., 1980). Ruminal fluid samples (200 mL) were drawn using a suction strainer, and $\mathrm{pH}$ was recorded using a pH meter and combination electrode (model 2000, Beckman Instruments Inc., Fullerton, CA). A 3-mL sample of ruminal fluid was retained, and $1 \mathrm{~mL}$ of $25 \%$ (wt/vol) $\mathrm{HPO}_{3}$ was added to the sample in a $12-\times 75-$ $\mathrm{mm}$ culture tube. Samples were stored at $-20^{\circ} \mathrm{C}$ until analysis for $\mathrm{NH}_{3}$ and VFA.

In situ bags were incubated from d 8 to 13. Dacron bags $(10 \times 20 \mathrm{~cm}, 50 \pm 15 \mu \mathrm{m}$ pore size, Ankom, Fairport, NY) containing 5 -g samples of ground alfalfa hay were incubated in the rumen to determine the effect of flax processing on rate and extent of forage digestion. The same kind of bags containing 5-g samples of flaxseed and linseed meal (physical form equal to treatment physical form) were also incubated in the rumen to examine digestibility differences between processing methods. Duplicate samples were incubated within lingerie bags, initially placed below ruminal mat layer in the ventral sac, in each steer for $0,2,5,9,12$, 
Table 1. Ingredients and chemical composition of experimental diets of Holstein steers fed flaxseed

\begin{tabular}{|c|c|c|c|c|}
\hline \multirow[b]{2}{*}{ Item } & \multicolumn{4}{|c|}{$\operatorname{Diet}^{1}$} \\
\hline & $\mathrm{CON}$ & WF & $\mathrm{RF}$ & GF \\
\hline \multicolumn{5}{|l|}{ Composition $^{2}$ (\% of DM) } \\
\hline Corn silage & 30.0 & 30.0 & 30.0 & 30.0 \\
\hline Alfalfa hay & 17.0 & 17.0 & 17.0 & 17.0 \\
\hline Beet pulp, shreds & 6.0 & 6.0 & 6.0 & 6.0 \\
\hline Corn, ground & 30.3 & 26.6 & 26.6 & 26.6 \\
\hline Linseed meal & 7.5 & - & - & - \\
\hline Whole flaxseed & - & 10.0 & - & - \\
\hline Rolled flaxseed & - & - & 10.0 & - \\
\hline Ground flaxseed & - & - & - & 10.0 \\
\hline Sunflower meal & 1.8 & 3.4 & 3.4 & 3.4 \\
\hline Feather meal & 3.0 & 2.6 & 2.6 & 2.6 \\
\hline Limestone $^{3}$ & 1.3 & 1.3 & 1.3 & 1.3 \\
\hline Corn gluten meal & 0.8 & 0.7 & 0.7 & 0.7 \\
\hline Blood meal & 0.8 & 0.7 & 0.7 & 0.7 \\
\hline Sodium bicarbonate $^{3}$ & 0.6 & 0.6 & 0.6 & 0.6 \\
\hline Magnesium oxide ${ }^{3}$ & 0.4 & 0.4 & 0.4 & 0.4 \\
\hline Urea & 0.2 & 0.3 & 0.3 & 0.3 \\
\hline Dairy Balancer $\mathrm{II}^{3}$ & 0.3 & 0.3 & 0.3 & 0.3 \\
\hline Salt & 0.1 & 0.1 & 0.1 & 0.1 \\
\hline Rumensin $80^{4}$ & 0.007 & 0.007 & 0.007 & 0.007 \\
\hline Chromic oxide & 0.3 & 0.3 & 0.3 & 0.3 \\
\hline \multicolumn{5}{|c|}{ Analyzed dietary nutrients (\% of DM) } \\
\hline $\mathrm{CP}$ & 18.0 & 17.8 & 17.5 & 17.4 \\
\hline NDF & 34.6 & 36.4 & 35.4 & 36.0 \\
\hline $\mathrm{ADF}$ & 18.0 & 19.5 & 18.8 & 19.1 \\
\hline FA & 4.4 & 4.9 & 5.0 & 5.3 \\
\hline
\end{tabular}

${ }^{1} \mathrm{CON}=$ control (linseed meal), WF $=$ whole flaxseed, $\mathrm{RF}=$ rolled flaxseed, and GF $=$ ground flaxseed.

${ }^{2}$ Forage-to-concentrate ratio for all rations was 53:47; $\mathrm{NE}_{\mathrm{L}}(\mathrm{Mcal} / \mathrm{kg})$ : $\mathrm{CON}=1.6, \mathrm{WF}, \mathrm{RF}$, and $\mathrm{GF}=1.7$.

${ }^{3}$ Dairy Balancer II (Nutrition Professionals Inc., Madison, WI; vitamins A, D, and E, microminerals, and selenium).

${ }^{4}$ Rumensin 80 (monensin; Elanco Animal Health, Greenfield, IN).

24, 34, 48, 72, and $120 \mathrm{~h}$. After removal, all bags were rinsed with water to remove large particulate matter. In situ bags were then rinsed in a top-loading washing machine (General Electric, Louisville, KY). Using the delicate cycle, the machine was filled with $45 \mathrm{~L}$ of cold water. The bags were agitated for $1 \mathrm{~min}$, drained, and spun for $2 \mathrm{~min}$. This cycle was repeated 5 times.

\section{In Situ Flaxseed Preparation}

Preparation of flaxseed for in situ degradability evaluation included removal of chaff and other impurities with a gravity table (Forsberg Inc., Thief River Falls, MN). Smaller impurities were then separated from the flaxseed using U.S.A. standard testing sieves (VWR Scientific, West Chester, PA), arranged (top to bottom) as follows: No. 10 (2 mm), No. 16 (1.19 $\mathrm{mm})$, and catch pan. The sieves were shaken with a Ro-Tap shaker (Testing Sieve Shaker, model no. 9221, The W. S. Tyler Company, Cleveland, $\mathrm{OH}$ ). Flaxseed underwent size reduction in a roller mill, with rollers aligned with minimum opening without binding, or were ground in a small batch grinder (model no. MG, Urschel Laboratories, Valparaiso, IN), with the cutting head (model no. 66900, Urschel Laboratories) set at a height of $0.05 \mathrm{~m}$ in a $1.22-\mathrm{m}$ column. The horizontal separators were $0.6 \mathrm{~mm}$ thick with a $1.0-\mathrm{mm}$ opening between separators. Whole flaxseed remained unprocessed, and alfalfa hay was ground in a Wiley mill (2-mm screen; Arthur H. Thomas, Philadelphia, PA) for in situ analysis. All physical forms of flaxseed were compared for particle size (Table 2) using a particle size analyzer (Micron Powder Systems, Hosokawa Micron, Summit, NJ). Samples $(20 \mathrm{~g})$ were vacuumed $(61.65$ $\mathrm{mmHg} ; 60 \mathrm{~s})$ through with USA Standard Test Sieves (Hosokawa Micron Powder Systems, $600 \mu \mathrm{m}-30$ mesh and $850 \mu \mathrm{m}-20$ mesh).

\section{Laboratory Analysis}

Orts and fecal samples were composited by animal, mixed in a rotary mixer (model H-600, Hobart Manufacturing Co.), and subsampled ( $10 \%$ of wet weight). Feed, orts, and fecal samples were subsequently dried in a $55^{\circ} \mathrm{C}$ forced-air oven (model SB-350, The Grieve Corporation, Round Lake, IL) for $48 \mathrm{~h}$. Dried samples were ground in a Wiley mill (2-mm screen; Arthur H. Thomas). Samples were composited within each of the 
Table 2. Effect of flaxseed processing on nutrient composition and particle size of flaxseed and linseed meal used in the study

\begin{tabular}{lcrrr}
\hline & & \multicolumn{3}{c}{ Processing method } \\
\cline { 3 - 5 } Item & $\begin{array}{c}\text { Linseed } \\
\text { meal }\end{array}$ & Whole & Rolled & Ground \\
\hline Composition (\% of DM) & & & & \\
Ash & 6.4 & 3.6 & 3.6 & 3.6 \\
CP & 38.0 & 24.8 & 25.1 & 25.2 \\
NDF & 20.9 & 36.3 & 33.3 & 34.3 \\
ADF & 12.4 & 18.3 & 18.1 & 18.1 \\
Ether extract & 4.3 & 36.3 & 37.2 & 32.8 \\
Particle size (\% remaining) & & & & 8.5 \\
$>850 \mu \mathrm{m}$ & 48.5 & 99.0 & 90.4 & 30.0 \\
$>600 \mu \mathrm{m}$ & 71.5 & 99.5 & 96.5 & \\
\hline
\end{tabular}

4 periods for analysis. Intestinal chyme samples were lyophilized and ground in a Wiley mill with a 1-mm screen. Diet, ruminal, duodenal, ileal, and fecal samples were analyzed for DM, ash, N, ether extract (methods 930.15, 940.05, 984.13, 945.16, respectively, AOAC International, 1997), as well as NDF (assayed with thermostable $\alpha$-amylase and sodium sulfite expressed inclusive of residual ash) and ADF (expressed inclusive of residual ash) concentration by the method of Robertson and Van Soest (1981) using a fiber analyzer (Ankom Technology Corp., Fairport, NY). Intestinal and fecal samples were also analyzed for Cr (Czarnocki et. al., 1961). Sample Cr and nutrient concentrations were used to estimate site of digestion and relative digestibility (Merchen, 1988).

Ruminal fluid was thawed and centrifuged $(10,000 \times$ $g$; $10 \mathrm{~min}$ ). Three milliliters of supernatant was mixed with $0.75 \mathrm{~mL}$ of $25 \%$ (wt/vol) meta-phosphoric acid and centrifuged again $(10,000 \times g ; 10 \mathrm{~min})$. Ruminal VFA concentrations were determined by GLC (Hewlett Packard 5890A Series II GC, Wilmington, DE) and separated on a capillary column (Nukol, Supelco, Bellefonte, PA) using 2-ethyl butyric acid as the internal standard (Goetsch and Galyean, 1983). A small portion $(0.6 \mathrm{~g})$ of the lyophilized duodenal samples was reconstituted to $3 \%(\mathrm{wt} / \mathrm{vol}$ ) in $0.1 \mathrm{~N} \mathrm{HCl}$, vortexed, and centrifuged at 20,000 $\times g$ for $20 \mathrm{~min}$ (Hannah et al., 1991). Supernatant from the duodenal and first ruminal centrifugation were used for $\mathrm{NH}_{3}-\mathrm{N}$ analysis (Broderick and Kang 1980). Cobalt concentration was determined using atomic absorption spectrometry (AAnalyst 800; PerkinElmer, Shelton, CT).

Ruminal bacteria were isolated from a $4-\mathrm{kg}$ sample of ruminal contents by blending with a Waring blender (model 37BL19 CB6; Waring Products, New Hartford, CT) and strained through 2 layers of cheesecloth. Feed particles and protozoa in ruminal samples were removed via centrifugation at $1,000 \times g$ for 10 min. Bacteria were separated from supernatant by centrifuging at $20,000 \times$ $g$ for $20 \mathrm{~min}$. Isolated bacteria were frozen and analyzed for DM (lyophilized), ash, N (as previously described), and purines (Zinn and Owens, 1986). Diet digestibility was determined by analyzing duodenal, ileal, and fecal samples for chromium concentrations (Fenton and Fenton, 1979).

\section{Calculations}

A corrected daily chromium dosage was calculated to take into account the amount of chromium recovered in feces and that removed through duodenal and ileal sampling. Fecal recovery of chromium was calculated by multiplying the measured fecal flow rate $(\mathrm{kg} / \mathrm{d})$ by the concentration of chromium in the fecal sample. The amount of chromium removed with duodenal or ileal samples was calculated by multiplying the mass of a sample by its DM and chromium concentrations. Duodenal flow rate was calculated by dividing the concentration of chromium measured at the duodenum into the sum of chromium recovered in feces and amounts of chromium removed at the duodenum and ileum. Ileal flow was calculated similarly to determine flow to the large intestine.

Microbial $\mathrm{OM}$ and $\mathrm{N}$ leaving the abomasum were calculated using purines as microbial markers (Zinn and Owens, 1986). Organic matter fermented in the rumen was $\mathrm{OM}$ intake minus the difference between the amount of total $\mathrm{OM}$ reaching the duodenum and microbial OM reaching the duodenum. Nonmicrobial $\mathrm{N}$ escape to the small intestine was calculated by subtracting microbial $\mathrm{N}$ from total $\mathrm{N}$ and thus includes any endogenous and ammonia $\mathrm{N}$ contributions. Fluid dilution rate was calculated using regression analysis of the natural logarithm of Co concentrations over time (Warner and Stacy, 1968).

\section{Statistical Analysis}

The statistical model used for all analyses included the main effects of diet, period (fixed effect), and steer 
(random effect). Data were analyzed as a $4 \times 4$ Latin square using PROC MIXED of SAS (version 9.1, SAS Institute, Cary, NC). The model included period, animal, and diet: $Y_{i j k}=\mu+T_{i}+P_{j}+c_{k}+e_{i j k l}$, where $Y_{i j k}$ $=$ dependent variable, $\mu=$ overall mean, $T_{i}=$ fixed effect of treatment $i(i=1, \ldots, 4), P_{j}=$ fixed effect of period $j(j=1, \ldots, 4) c_{k}=$ random effect of steer $k(k=$ $1, \ldots, 4) \quad N \sim\left(0, \sigma_{c}^{2}\right), \quad$ and $e_{i j k}=$ random residual $N \sim\left(0, \sigma_{e}^{2}\right)$. Means were expressed as least squares means and considered different at $P \leq 0.05$. Preplanned orthogonal contrasts compared control versus flaxseed, whole flaxseed versus processed flaxseed, and ground flaxseed versus rolled flaxseed.

In situ disappearance data were fitted to the model designed by Ørskov and McDonald (1979) using the nonlinear procedures of SAS (SAS Institute Inc.). The equation was $p=a+b\left(1-e^{-c t}\right)$, where $p$ is disappearance, $a$ is the rapidly degraded fraction, $b$ is the slowly degraded fraction, $c$ is the disappearance rate, and $t$ is time.

\section{RESULTS AND DISCUSSION}

\section{Particle Size and Nutrient Composition of Flaxseed}

Particle size data are presented in Table 2. Rolling and grinding flaxseed resulted in 90.4 and $8.5 \%$, respectively, of particles $>850 \mu \mathrm{m}$ compared with the whole flaxseed, which had $99 \%$ of particles $>850 \mu \mathrm{m}$. The particle size of the control sample was $48.5 \%>850$ $\mu \mathrm{m}$. The whole, rolled, and ground flaxseed had 99.5, 96.5 , and $30.0 \%$, respectively, of particles $>600 \mu \mathrm{m}$. Our intent when processing the rolled flaxseed was to coarsely open the seed coat to allow ruminal microbes access to the inner-seed meal; therefore, particle size measurement may not be accurate in revealing the potential for efficiency of degradation. Nutrient composition of processed flaxseed appeared similar (Table 2 ). Numerically, NDF was slightly greater for whole flaxseed, and fat level was greater for rolled flaxseed. As expected, linseed meal had increased ash and CP values but lower fiber and fat levels. Lardy and Anderson (2009) reported the proximate analysis of flaxseed to include $22.8 \% \mathrm{CP}, 35 \%$ lipid, and $8 \%$ ADF. Flaxseed ranges in protein values from 18.8 to $24.4 \%$ (Daun and Przybylski, 2000).

\section{Diets and Intake}

Dietary CP ranged from $17.37 \%$ for the ground flaxseed diet to $17.95 \%$ for the control diet (Table 1). Dry matter intake was similar among treatments (11.92 \pm $0.86 \mathrm{~kg} / \mathrm{d} ; P=0.59$; data not shown). These results are in agreement with Petit (2002) and Ward et. al. (2002), who found that untreated flaxseed supplementation at levels up to $15 \%$ of the dietary DM did not affect DMI of Holstein cows. Formaldehyde-treated flaxseed fed up to $15 \%$ of dietary DM had no effect on DMI (Petit, 2002). Feeding other oilseeds such as canola or sunflower have resulted in similar findings (Khorasani et al., 1991; Chichlowski et al., 2005).

Dry matter intake expressed as a percentage of BW $(2.41 \pm 0.17$, data not shown; $P=0.78)$ was also similar for steers fed flaxseed that was processed. Even though supplemental dietary fat from plant sources can lower intake, our research found no significant effects of adding $4.1 \%$ fat from flaxseed when supplemented according to NRC (2001) guidelines with a 53:47 forage:concentrate ratio.

\section{Digestion and Fermentation}

Treatment had no effect on apparent and true OM digestion in the rumen $(P \geq 0.43$; Table 3$)$. Our results are in agreement with Gonthier et al. (2004), who compared raw, micronized, and extruded flaxseed. Large intestine, small intestine, and total-tract $\mathrm{OM}$ digestibilities were also similar for all treatments $(P \geq 0.15$; Table 3). However, linseed meal tended $(P=0.06$; Table 3) to have greater total-tract OM digestibility when compared with all physical forms of flaxseed. Gonthier et al. (2004) reported that diets with flaxseed improved postruminal OM and total-tract OM digestibility (expressed as a percent of passage to duodenum and percent of intake, respectively) compared with a control diet containing no flaxseed.

In another Canadian trial comparing ground and whole flaxseed, ground flaxseed tended $(P=0.07)$ to increase OM digestibility (da Silva et al., 2007). Pires et al. (1997) found that grinding cottonseed increased total-tract digestibility of $\mathrm{OM}$ when compared with whole-raw, whole-roasted, or ground-roasted cottonseed and a control. Scott et al. (1991) compared roasting, extrusion, and reducing particle size of soybeans by utilizing treatments of rolled-raw, finely ground-raw, roasted, and extruded soybeans and found that apparent digestibility of nutrients in the entire digestive tract were greatest for rolled-raw soybeans. Tice et al. (1993) compared whole-raw, whole-roasted, crackedroasted, and ground-roasted soybeans to a control diet that contained no soybeans and found no differences in total-tract digestibility of OM. In the control diet, urea and casein provided $59 \%$ of the $\mathrm{CP}$ equivalent.

In our study, we adjusted the control diet to account for the protein contribution from flaxseed; flaxseed (linseed) meal was included in the formulation to provide concentrations of amino acids similar to the other diets. 
Table 3. Effect of flaxseed processing on OM intake, flow, and digestion in dairy lactation diets offered to Holstein steers

\begin{tabular}{|c|c|c|c|c|c|c|c|c|c|}
\hline Item & \multicolumn{4}{|c|}{ Physical form of flaxseed ${ }^{1}$} & $\mathrm{SEM}^{2}$ & $P$-value ${ }^{3}$ & \multicolumn{3}{|c|}{ Contrast $^{4}$} \\
\hline Intake $(\mathrm{kg} / \mathrm{d})$ & 10.76 & 10.28 & 11.12 & 11.43 & 0.78 & 0.61 & 0.80 & 0.23 & 0.74 \\
\hline \multicolumn{10}{|l|}{ Duodenal flow $(\mathrm{kg} / \mathrm{d})$} \\
\hline Bacterial & 1.18 & 1.37 & 1.68 & 1.67 & 0.22 & 0.19 & 0.08 & 0.19 & 0.97 \\
\hline Apparent feed & 3.16 & 3.22 & 2.93 & 3.24 & 0.64 & 0.87 & 0.94 & 0.72 & 0.49 \\
\hline \multicolumn{10}{|c|}{ Digestibility ( $\%$ of intake) } \\
\hline Apparent ruminal & 67.07 & 63.64 & 65.12 & 64.28 & 5.19 & 0.65 & 0.29 & 0.62 & 0.79 \\
\hline True ruminal & 78.00 & 76.46 & 80.08 & 78.62 & 4.10 & 0.43 & 0.83 & 0.16 & 0.51 \\
\hline Small intestine & 9.91 & 11.06 & 8.76 & 10.31 & 2.09 & 0.64 & 0.93 & 0.36 & 0.41 \\
\hline Large intestine & 4.98 & 5.80 & 7.27 & 5.66 & 1.75 & 0.30 & 0.21 & 0.51 & 0.19 \\
\hline Total tract & 81.96 & 80.20 & 81.14 & 80.25 & 1.58 & 0.15 & 0.06 & 0.47 & 0.27 \\
\hline
\end{tabular}

${ }^{1}$ Physical forms of flaxseed include $\mathrm{CON}=$ control (linseed meal), $\mathrm{WF}=$ whole flaxseed, $\mathrm{RF}=$ rolled flaxseed, and $\mathrm{GF}=$ ground flaxseed. ${ }^{2} \mathrm{n}=4$ observations per treatment.

${ }^{3}$ Probability value for the $F$-test of overall treatment.

${ }^{4}$ Contrasts include $1=$ control versus the average of whole, rolled, and ground flaxseed; 2 = whole flaxseed versus the average of rolled and ground flaxseed; and $3=$ rolled flaxseed versus ground flaxseed.

Other studies have reported that protein digestion is not changed by adding fat to the diet (Grainger et al., 1961; Boggs et al., 1987). Our study is in agreement with these findings as we found no differences in CP intake (by design), duodenal CP flow (bacterial, apparent feed, or total), ileal CP flow, fecal CP output, microbial efficiency, or $\mathrm{CP}$ digestibility (apparent ruminal, true ruminal, small intestine, large intestine, or total tract; $P \geq 0.44$; Table 4). Unlike Tice et al. (1993), who fed whole soybeans, we did not observe reduced bacterial protein flow to the duodenum with the different treatments. Aldrich et al. (1995) reported similar findings with steers fed raw and roasted soybeans. Coppock et al. (1985) reported a decrease in CP digestibility for whole, acid-delinted cottonseed compared with rolled, acid-delinted cottonseed. They attributed the greater loss of nutrients from the whole cottonseed diet to passage of more intact seeds in the feces. We did not investigate feces for whole flaxseeds. Gonthier et al. (2004) found that extruded flaxseed had greater ruminal and lower postruminal CP digestibility; however, they found that total-tract CP digestibility of heat-treated flaxseed was similar to ground flaxseed. Increases in total-tract $\mathrm{CP}$ digestibility have also been reported with ground flaxseed compared with whole flaxseed (da Silva et al., 2007). Scott et al. (1991) reported lower total-tract CP digestibility for ground raw soybeans compared with extruded soybeans. In our study, flaxseed contributed approximately $14.5 \%$ of the total dietary CP and, with greater inclusion levels, it is possible that $\mathrm{CP}$ digestibility may be affected by processing flaxseed, but this was not detected in the present study.
The findings from the present study provide indirect evidence that microbial efficiency was unaffected by the addition of fat in the form of flaxseed to the diet when microbial efficiency ( $\mathrm{g}$ of microbial $\mathrm{N} / \mathrm{kg}$ of $\mathrm{OM}$ truly fermented) was used as an indicator of microbial activity $(P=0.96$; Table 4$)$. Because no differences were noted in $\mathrm{CP}$ and $\mathrm{OM}$ digestibility, one might expect no differences in microbial efficiency. When Tice et al. (1993) investigated roasted soybean processing, no differences in microbial efficiency were detected due to either added fat or processing. However, Gonthier et al. (2004) found that microbial efficiency was reduced with raw, micronized, and extruded ( $12.7 \%$ of diet DM) flaxseed compared with a control diet containing no flaxseed when nutrient requirements were met with greater levels of the basal ingredients.

In our study, flaxseed processing had no effect on total-tract NDF or ADF digestion with inclusion levels of $10 \%$ of dietary DM (Table 5$)$. No differences $(P$ $\geq 0.38$ ) in NDF and ADF intake, duodenal flow, ileal flow, fecal output, or digestibility were noted. Grinding, roasting, and extruding soybeans has led to decreased NDF digestibility (Scott et al., 1991). Sullivan et al. (1993) reported no fiber differences with cottonseed, whereas Pires et al. (1997) reported increases in NDF digestibility with the grinding of cottonseed. In contrast, Reveneau et al. (2005) reported no differences in NDF digestibility when altering particle sizes or delinting cottonseed. da Silva et al. (2007) reported decreased ADF digestibility with ground flaxseed compared with whole flaxseed. Micronized flaxseed reduced ruminal NDF fermentation and increased postruminal NDF di- 
Table 4. Effect of flaxseed processing on CP intake, flow, and digestion in dairy lactation diets offered to Holstein steers

\begin{tabular}{|c|c|c|c|c|c|c|c|c|c|}
\hline Item & \multicolumn{4}{|c|}{ Physical form of flaxseed ${ }^{1}$} & $\mathrm{SEM}^{2}$ & $P$-value ${ }^{3}$ & \multicolumn{3}{|c|}{ Contrast $^{4}$} \\
\hline Intake $(\mathrm{kg} / \mathrm{d})$ & 2.06 & 1.94 & 2.09 & 2.14 & 0.16 & 0.70 & 0.99 & 0.28 & 0.80 \\
\hline Bacterial & 0.62 & 0.58 & 0.68 & 0.70 & 0.10 & 0.59 & 0.65 & 0.23 & 0.85 \\
\hline Apparent feed & 0.76 & 0.77 & 0.70 & 0.75 & 0.14 & 0.90 & 0.87 & 0.63 & 0.62 \\
\hline Total & 1.37 & 1.35 & 1.38 & 1.45 & 0.22 & 0.94 & 0.87 & 0.67 & 0.70 \\
\hline \multicolumn{10}{|c|}{ Digestibility (\% of intake) } \\
\hline Apparent ruminal & 33.65 & 31.15 & 33.78 & 32.94 & 9.18 & 0.96 & 0.82 & 0.65 & 0.88 \\
\hline True ruminal & 63.66 & 60.59 & 66.18 & 65.10 & 6.27 & 0.44 & 0.92 & 0.14 & 0.76 \\
\hline Small intestine & 38.73 & 39.10 & 36.89 & 38.40 & 6.14 & 0.94 & 0.85 & 0.68 & 0.71 \\
\hline Large intestine & 4.63 & 5.32 & 6.18 & 4.42 & 1.23 & 0.47 & 0.50 & 0.99 & 0.17 \\
\hline Total tract & 77.02 & 75.57 & 76.85 & 75.76 & 2.10 & 0.55 & 0.36 & 0.50 & 0.39 \\
\hline
\end{tabular}

${ }^{1}$ Physical forms of flaxseed include $\mathrm{CON}=$ control (linseed meal), $\mathrm{WF}=$ whole flaxseed, $\mathrm{RF}=$ rolled flaxseed, and $\mathrm{GF}=$ ground flaxseed. ${ }^{2} \mathrm{n}=4$ observations per treatment.

${ }^{3}$ Probability value for the $F$-test of overall treatment.

${ }^{4}$ Contrasts include $1=$ control versus the average of whole, rolled, and ground flaxseed; $2=$ whole flaxseed versus the average of rolled and ground flaxseed; and 3 = rolled flaxseed versus ground flaxseed.

${ }^{5}$ Grams of microbial N/kg of OM truly fermented; truly fermented OM = OM intake - apparent feed OM flow at the duodenum.

gestion, but did not affect total-tract NDF digestibility (Mustafa et al., 2002). Our results are in contrast to those of Gonthier et al. (2004), who reported greater NDF digestibility with flaxseed inclusion $(12.7 \%$ of dietary DM) for which they attributed greater digestibilities of the flaxseed fiber constituents than those of the basal diet. However, in their study, total-tract ADF digestibilities (percentage of intake) were unaffected $(P$ $=0.97$ ).

No time by treatment interactions were apparent for ruminal $\mathrm{pH}$, ammonia, and VFA concentration (data not shown; $P \geq 0.54$ ). Flaxseed processing had no effect on ruminal $\mathrm{pH}$, ammonia, or VFA concentration $(P$ $\geq 0.40$; Table 5$)$. These results are in agreement with our nutrient digestion and microbial efficiency results. They indicate similar fiber digestion and similar VFA concentrations among treatments, indicative of similar ruminal fermentation among steers fed processed flaxseed. Gonthier et al. (2004) also reported no differences in the average values of ruminal $\mathrm{pH}, \mathrm{NH}_{3}-\mathrm{N}$, or total VFA. Other studies evaluating processed oilseeds have shown no effect on ruminal pH (Scott et al., 1991; Reveneau et al., 2005), $\mathrm{NH}_{3}-\mathrm{N}$ (Pires et al., 1997), and total VFA production (Pires et al., 1997; Reveneau et al., 2005).

Most studies that reported differences in individual VFA also reported differences in ruminal fiber digestion (Scott et al., 1991; Pires et al., 1997; Gonthier et al., 2004). The data from the microbial efficiency and the rumen fermentation parameters indicate that microbial activity was likely not influenced by the flax processing treatments utilized in this study. This may be due to the relatively low inclusion levels of flaxseed in the diet $(10 \%$ of diet DM). In addition, rumination may have provided further processing of the flaxseed by the animals used in the study (Welch and Hooper, 1993).

We anticipated relative differences of the digestive measures among treatments from Holstein steers to be similar to that of dairy cows fed mid-lactation diets. Multiple citations in the literature report on the use of Holstein steers or nonlactating Holstein cows to compare the effects of a variety of fat sources on digestion and fermentation (Elliott et al., 1994, 1997). The demands of milk synthesis increase DMI in lactating cows beyond that of growing steers or nonlactating cows, which may result in a shift in the site to postruminal digestion, although direct comparisons in the literature are lacking. In work conducted in beef cattle, lactation resulted in greater DMI compared with nonpregnant controls, but OM digestion was not different, even though the passage rate of indigestible ADF was greater (Vanzant et. al, 1991). Based on the published literature, we are confident that the relative treatment differences identified in this study are applicable to diets for lactating cows.

\section{In Situ Degradability of Linseed Meal and Flaxseed}

We detected differences $(P \leq 0.03)$ in DM soluble percentage, slowly degradable portion, degradation rate, and extent of degradability for steers fed linseed meal, ground flaxseed, rolled flaxseed, or whole flaxseed DM among dietary treatments. Figure 1 indicates the percent in situ disappearance over time for linseed meal, as 
Table 5. Effect of flaxseed processing on intake, flow, and digestion of NDF and ADF, pH, ammonia, and VFA in dairy lactation diets offered to Holstein steers

\begin{tabular}{|c|c|c|c|c|c|c|c|c|c|}
\hline \multirow[b]{2}{*}{ Item } & \multicolumn{4}{|c|}{ Physical form of flaxseed ${ }^{1}$} & \multirow[b]{2}{*}{$\mathrm{SEM}^{2}$} & \multirow[b]{2}{*}{$P$-value ${ }^{3}$} & \multicolumn{3}{|c|}{ Contrast $^{4}$} \\
\hline & $\mathrm{CON}$ & WF & $\mathrm{RF}$ & GF & & & 1 & 2 & 3 \\
\hline \multicolumn{10}{|l|}{ NDF } \\
\hline Intake $(\mathrm{kg} / \mathrm{d})$ & 4.16 & 4.15 & 4.41 & 4.65 & 0.31 & 0.51 & 0.43 & 0.27 & 0.54 \\
\hline Duodenal flow (kg/d) & 0.87 & 0.97 & 0.81 & 0.93 & 0.12 & 0.59 & 0.74 & 0.37 & 0.36 \\
\hline Ileal flow $(\mathrm{kg} / \mathrm{d})$ & 1.05 & 1.14 & 1.23 & 1.24 & 0.18 & 0.38 & 0.15 & 0.38 & 0.94 \\
\hline Fecal output (kg/d) & 1.10 & 1.12 & 1.16 & 1.24 & 0.12 & 0.51 & 0.39 & 0.35 & 0.43 \\
\hline Total-tract digestibility (\% of intake) & 73.73 & 72.94 & 73.79 & 73.11 & 2.23 & 0.96 & 0.79 & 0.77 & 0.74 \\
\hline \multicolumn{10}{|l|}{$\mathrm{ADF}$} \\
\hline Intake $(\mathrm{kg} / \mathrm{d})$ & 2.21 & 2.28 & 2.39 & 2.49 & 0.15 & 0.49 & 0.28 & 0.36 & 0.60 \\
\hline Duodenal flow (kg/d) & 0.49 & 0.54 & 0.44 & 0.50 & 0.06 & 0.61 & 0.92 & 0.31 & 0.42 \\
\hline Ileal flow $(\mathrm{kg} / \mathrm{d})$ & 0.65 & 0.70 & 0.73 & 0.75 & 0.11 & 0.62 & 0.27 & 0.59 & 0.78 \\
\hline Fecal output (kg/d) & 0.65 & 0.67 & 0.69 & 0.73 & 0.07 & 0.52 & 0.34 & 0.41 & 0.45 \\
\hline Total-tract digestibility (\% of intake) & 70.76 & 70.47 & 71.23 & 70.11 & 2.58 & 0.97 & 0.94 & 0.93 & 0.65 \\
\hline $\mathrm{pH}$ & 6.64 & 6.59 & 6.67 & 6.60 & 0.09 & 0.91 & 0.85 & 0.66 & 0.59 \\
\hline Ammonia $(\mathrm{m} M)$ & 7.23 & 8.28 & 7.82 & 7.70 & 0.48 & 0.56 & 0.27 & 0.40 & 0.86 \\
\hline \multicolumn{10}{|l|}{ VFA } \\
\hline Acetate $(\mathrm{mol} / 100 \mathrm{~mol})$ & 63.56 & 63.19 & 62.57 & 63.28 & 0.88 & 0.88 & 0.60 & 0.81 & 0.58 \\
\hline Propionate $(\mathrm{mol} / 100 \mathrm{~mol})$ & 18.21 & 17.43 & 18.01 & 18.09 & 0.50 & 0.70 & 0.54 & 0.33 & 0.91 \\
\hline Isobutyrate (mol/100 mol) & 1.99 & 2.00 & 2.09 & 1.96 & 0.12 & 0.89 & 0.86 & 0.89 & 0.46 \\
\hline Butyrate $(\mathrm{mol} / 100 \mathrm{~mol})$ & 2.16 & 2.06 & 2.13 & 2.05 & 0.12 & 0.89 & 0.57 & 0.82 & 0.66 \\
\hline Isovaleric $(\mathrm{mol} / 100 \mathrm{~mol})$ & 11.00 & 11.73 & 11.35 & 10.70 & 0.43 & 0.40 & 0.21 & 0.31 & 0.59 \\
\hline Valeric $(\mathrm{mol} / 100 \mathrm{~mol})$ & 3.38 & 3.58 & 3.83 & 3.61 & 0.27 & 0.71 & 0.36 & 0.68 & 0.58 \\
\hline Total $(\mathrm{m} M)$ & 112.29 & 113.66 & 109.01 & 116.40 & 6.12 & 0.86 & 0.92 & 0.90 & 0.41 \\
\hline Acetate:propionate & 3.63 & 3.76 & 3.62 & 3.63 & 0.14 & 0.89 & 0.81 & 0.45 & 0.94 \\
\hline Acetate:butyrate:propionate & 3.75 & 3.87 & 3.74 & 3.75 & 0.14 & 0.89 & 0.83 & 0.46 & 0.96 \\
\hline
\end{tabular}

곡 ${ }^{1}$ Physical forms of flaxseed include $\mathrm{CN}=$ control (linseed meal), WF = whole flaxseed, $\mathrm{RF}=$ rolled flaxseed, and GF $=$ ground flaxseed.

$\quad{ }^{2} \mathrm{n}=4$ observations per treatment.

글 ${ }^{3}$ Probability value for the $F$-test of overall treatment.

$\stackrel{D_{\Sigma}}{\stackrel{\Perp}{\Sigma}} \quad{ }^{4}$ Contrasts include $1=$ control versus the average of whole, rolled, and ground flaxseed; $2=$ whole flaxseed versus the average of rolled and ground flaxseed; and $3=$ rolled flaxseed () versus ground flaxseed. 
Table 6. In situ degradation kinetics of linseed, flaxseed, and alfalfa fractions in Holstein steers offered dairy lactation diets

\begin{tabular}{|c|c|c|c|c|c|c|c|c|c|}
\hline Item & \multicolumn{4}{|c|}{ Diet treatment ${ }^{1}$} & SEM & $P$-value ${ }^{2}$ & \multicolumn{3}{|c|}{ Contrast $^{3}$} \\
\hline \multicolumn{10}{|l|}{ Processed flaxseed } \\
\hline Soluble $(\%)$ & 30.4 & -0.7 & 5.8 & 33.1 & 3.4 & $<0.01$ & $<0.01$ & $<0.01$ & $<0.01$ \\
\hline Slowly degradable (\%) & 56.8 & 94.8 & 82.8 & 55.4 & 3.5 & $<0.01$ & $<0.01$ & $<0.01$ & $<0.01$ \\
\hline Degradation rate $(\% / \mathrm{h})$ & 7.46 & 0.57 & 4.53 & 11.25 & 0.49 & $<0.01$ & $<0.01$ & $<0.01$ & $<0.01$ \\
\hline Soluble (\%) & 31.7 & -7.4 & 2.7 & 38.1 & 4.2 & $<0.01$ & $<0.01$ & $<0.01$ & $<0.01$ \\
\hline Slowly degradable (\%) & 64.5 & 98.7 & 95.8 & 58.7 & 3.7 & $<0.01$ & $<0.01$ & $<0.01$ & $<0.01$ \\
\hline Degradation rate $(\% / \mathrm{h})$ & 7.58 & 1.03 & 5.09 & 11.43 & 0.47 & $<0.01$ & $<0.01$ & $<0.01$ & $<0.01$ \\
\hline Extent degradability (\%) & 96.2 & 91.3 & 98.6 & 96.7 & 1.0 & $<0.01$ & 0.18 & $<0.01$ & 0.07 \\
\hline \multicolumn{10}{|l|}{ Fat } \\
\hline Soluble (\%) & 71.3 & -11.2 & 22.5 & 60.3 & 9.2 & $<0.01$ & 0.02 & $<0.01$ & 0.01 \\
\hline Slowly degradable (\%) & 26.2 & 100.0 & 77.5 & 39.2 & 8.9 & $<0.01$ & 0.02 & $<0.01$ & $<0.01$ \\
\hline Slowly degradable (\%) & 52.4 & 52.9 & 53.4 & 47.2 & 3.0 & 0.50 & 0.16 & 0.99 & 0.81 \\
\hline Degradation rate $(\% / \mathrm{h})$ & 6.32 & 5.90 & 5.90 & 6.20 & 0.78 & 0.97 & 0.87 & 0.84 & 0.71 \\
\hline Extent degradability (\%) & 78.4 & 78.7 & 79.7 & 81.1 & 2.0 & 0.63 & 0.27 & 0.85 & 0.57 \\
\hline \multicolumn{10}{|l|}{$\mathrm{CP}$} \\
\hline Soluble $(\%)$ & 38.2 & 38.9 & 34.8 & 44.4 & 6.2 & 0.71 & 0.33 & 0.75 & 0.69 \\
\hline Slowly degradable $(\%)$ & 53.0 & 52.4 & 56.9 & 48.3 & 5.4 & 0.73 & 0.38 & 0.70 & 0.62 \\
\hline Degradation rate $(\% / \mathrm{h})$ & 10.16 & 9.68 & 9.96 & 9.67 & 1.08 & 0.98 & 0.84 & 0.78 & 0.90 \\
\hline Extent degradability (\%) & 91.2 & 91.3 & 91.7 & 92.7 & 1.3 & 0.48 & 0.17 & 0.84 & 0.62 \\
\hline \multicolumn{10}{|l|}{ NDF } \\
\hline Soluble $(\%)$ & -6.3 & -5.8 & -4.1 & -6.0 & 2.0 & 0.86 & 0.79 & 0.82 & 0.47 \\
\hline Slowly degradable $(\%)$ & 71.0 & 71.9 & 71.7 & 73.6 & 3.8 & 0.95 & 0.60 & 0.89 & 0.88 \\
\hline Degradation rate $(\% / \mathrm{h})$ & 4.93 & 4.44 & 4.40 & 6.42 & 0.64 & 0.07 & 0.02 & 0.71 & 0.46 \\
\hline Extent degradability (\%) & 64.8 & 66.2 & 67.6 & 67.5 & 2.5 & 0.77 & 0.60 & 0.99 & 0.39 \\
\hline \multicolumn{10}{|l|}{$\mathrm{ADF}$} \\
\hline
\end{tabular}

${ }^{1}$ In situ treatments of processed flaxseed $[\mathrm{CON}=$ control (linseed meal); GF $=$ ground flaxseed; $\mathrm{RF}=$ rolled flaxseed; and $\mathrm{WF}=$ whole flaxseed] was equal to the steers' dietary treatment for a given period, and all steers for all periods also had incubated chopped alfalfa in situ bags. ${ }^{2}$ Significance of the $F$-test.

${ }^{3}$ Contrasts include $1=$ control versus the average of whole, rolled, and ground flaxseed; 2 = whole flaxseed versus the average of rolled and ground flaxseed; $3=$ rolled flaxseed versus ground flaxseed.

well as whole, rolled, and ground flaxseed. Linseed meal and ground flaxseed had the greatest soluble percent (A fraction) for DM, CP, and fat (Table 6). The high solubility of these 2 treatments was likely the result of the small particle size. As the particle size of flaxseed increased, soluble percentages decreased, with the percentage of whole flaxseed not being different $(-0.70 \pm$ 3.40) from zero because of the high portion of the flaxseed meal and ground flaxseed that had already degraded or disappeared. The flaxseed meal and ground flaxseed had much lower slowly degradable portions compared with whole flaxseed and rolled flaxseed. These values may be exaggerated relative to the fit of the model for whole flaxseed. The ground flaxseed treatment had the fastest in situ DM degradation rate $(11.25 \% / \mathrm{h} ; P<$
$0.01)$, followed by linseed meal $(7.46 \% / \mathrm{h} ; P<0.01)$, rolled flaxseed $(4.53 \% / \mathrm{h} ; P<0.01)$, and whole flaxseed $(0.57 \% / \mathrm{h} ; P<0.01$; Table 6$)$. Degradability of CP and fat followed the same pattern as DM degradability for in situ processed flaxseed. The results from the whole flaxseed diet indicate a strong linear degradation rate. Our in situ study was conducted to $120 \mathrm{~h}$ in an attempt to reach a plateau on the rate of degradation for whole flaxseed. We did not approach the plateau at $120 \mathrm{~h}$ but the nonlinear model did converge. If one were to assume a $5 \% / \mathrm{h}$ ruminal passage rate, about $10 \%$ of whole flax would be effectively degraded in the rumen. Other studies that evaluated oilseed processing have reported similar in situ results. Reveneau et al. (2005) reported an increase in degradation rates for 


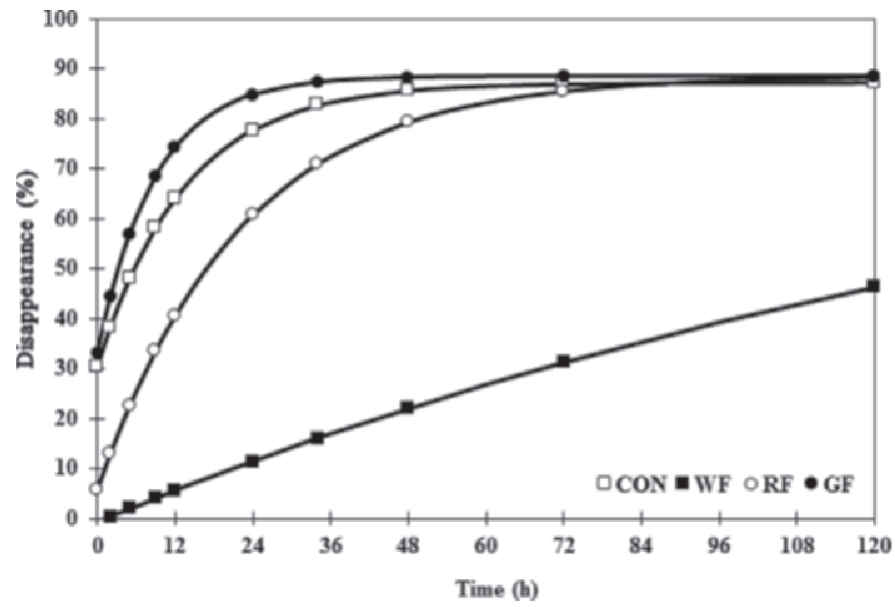

Figure 1. In situ disappearance (DM) for processed flaxseed in Holstein steers offered dairy lactation diets (contrasts: linseed meal vs. the average of whole, rolled, and ground flaxseed, $P<0.01$; whole flaxseed vs. the average of rolled and ground flaxseed, $P<0.01$; rolled flaxseed vs. ground flaxseed, $P<0.01)$. In situ treatments of processed flaxseed $[\mathrm{CON}=$ control (linseed meal); $\mathrm{GF}=$ ground flaxseed; $\mathrm{RF}$ $=$ rolled flaxseed; and $\mathrm{WF}=$ whole flaxseed] was equal to the steers' dietary treatment for a given period, and all steers for all periods also had incubated chopped alfalfa in situ bags.

conventional small, whole cottonseed pellets compared with whole cottonseed. However, Mustafa et al. (2002) reported reductions in degradation rates of micronized flaxseed versus whole flaxseed.

\section{In Situ Degradability of Alfalfa Hay}

To determine if flaxseed oil had an effect on ruminal fiber degradability, we incubated alfalfa hay in situ (Table 6). Doreau et al. (1991), Ferlay et al. (1992), and Khorasani et al. (1992) concluded that no differences existed for ruminal in situ DM degradation of hay samples among treatments with diets containing different levels of fat. Our study results concur. Dry matter and $\mathrm{CP}$ degradation kinetics of chopped alfalfa hay $(16.4 \% \mathrm{CP}, 51.7 \% \mathrm{NDF}$, and $32.8 \% \mathrm{ADF}$; DM basis) were not different $(P \geq 0.48)$ for all dietary treatments. The slowly degradable fraction of alfalfa hay DM ranged from 47 to $52 \%(P=0.50)$, whereas the extent of degradation ranged from 78 to $81 \%(P=$ $0.63)$. The slowly degradable $\mathrm{CP}$ of alfalfa hay ranged from 48 to $57 \%(P=0.73)$, and the extent of degradation ranged from 91 to $93 \%(P=0.48)$.

We anticipated a faster release of lipid from processed flaxseed compared with the whole flaxseed treatment, which may alter fiber degradation. However, such results were not apparent in our study. In fact, the ground flaxseed treatment tended $(P \leq 0.07)$ to have the fastest rates of degradation for both NDF and ADF. These observations further indicate that our diets were not high enough in lipid to hinder fiber digestion, but instead the rate of digestion of the ground flaxseed may have caused a rapid release of $\mathrm{CP}$ to the rumen microorganisms, aiding in fiber digestion in the rumen (Jenkins, 1993). These results agree with Scott et al. (1991), who reported no in situ differences for alfalfa hay DM and NDF degradation rates for diets containing rolled raw, ground raw, extruded, and roasted soybeans, and dried distillers grains.

\section{CONCLUSIONS}

Dry matter intake expressed as a percentage of BW was similar for the flaxseed treatments and the control. Although we hypothesized that whole flaxseed would be less digestible, no major differences were detected for the digestion and ruminal fermentation of diets supplemented with similar levels of whole, rolled, and ground flaxseed and flaxseed meal. It is reasonable to expect differences to be relative among treatments but caution is warranted when applying data from steers directly to lactating dairy cows. Nevertheless, we conclude that whole flaxseed has very low rate of ruminal degradation and either rolling or grinding is an acceptable way of mechanically processing flaxseed for use in lactation diets.

\section{ACKNOWLEDGMENTS}

The authors thank the North Dakota Oilseed Council (Mandan, ND) and Ameriflax (Bismarck, ND) for funding this research.

\section{REFERENCES}

Aldrich, C. G., N. R. Merchen, D. R. Nelson, and J. A. Barmore. 1995. The effects of roasting temperature applied to whole soybeans on site of digestion by steers: II. Protein and amino acid digestion. J. Anim. Sci. 73:2131-2140.

Allen, M. S. 2000. Effects of diet on short-term regulation of feed intake by lactating dairy cattle. J. Dairy Sci. 83:1598-1624.

AOAC International. 1997. Official Methods of Analysis. 16th ed. AOAC International, Arlington, VA.

Boggs, D. L., W. G. Bergen, and D. R. Hawkins. 1987. Effects of tallow supplementation and protein withdrawal on ruminal fermentation, microbial synthesis and site of digestion. J. Anim. Sci. 64:907-914.

Broderick, G. A., and J. H. Kang. 1980. Automated simultaneous determination of ammonia and total amino acids in ruminal fluid and in vitro media. J. Dairy Sci. 63:64-75.

Chichlowski, M. W., J. W. Schroeder, C. S. Park, W. L. Keller, and D. E. Schimek. 2005. Altering the fatty acids in milk fat by including canola seed in dairy cattle diets. J. Dairy Sci. 88:3084-3094.

Coppock, C. E., J. R. Moya, J. W. West, D. H. Nave, J. M. Labore, and C. E. Gates. 1985. Effect of lint on whole cottonseed passage and digestibility and diet choice on intake of whole cottonseed by Holstein cows. J. Dairy Sci. 68:1198-1206.

Czarnocki, J., I. R. Sibbald, and E. V. Evans. 1961. The determination of chromic oxide in samples of feed and excreta by acid digestion and spectrophotometry. Can. J. Anim. Sci. 4:167-179. 
da Silva, D. C., G. T. Santos, A. F. Branco, J. C. Damasceno, R. Kazama, M. Matsushita, J. A. Horst, W. B. R. dos Santos, and H. V. Petit. 2007. Production, performance and milk composition of dairy cows fed whole or ground flaxseed with or without monensin. J. Dairy Sci. 90:2928-2936.

Daun, J. K., and R. Przybylski. 2000. Environmental effects on the composition of four Canadian flax cultivars. Pages 80-91 in Proc. 58th Flax Institute, Fargo, ND. Flax Institute, Fargo, ND.

Doreau, M., F. Legay, and D. Bauchart. 1991. Effect of source and level of supplemental fat on total and ruminal organic matter and nitrogen digestion in dairy cows. J. Dairy Sci. 74:2233-2242.

Elliott, J. P., J. K. Drackley, C. G. Aldrich, and N. R. Merchen. 1997. Effects of saturation and esterification of fat sources on site and extent of digestion in steers: Ruminal fermentation and digestion of organic matter, fiber, and nitrogen. J. Anim. Sci. 75:2803-2812.

Elliott, J. P., T. R. Overton, and J. K. Drackley. 1994. Digestibility and effects of three forms of mostly saturated fatty acids. J. Dairy Sci. 77:789-798.

Fenton, T. W., and M. Fenton. 1979. An improved procedure for the determination of chromic oxide in feed and feces. Can. J. Anim. Sci. 59:631-634.

Ferlay, A., F. Legay, D. Bauchart, C. Poncet, and M. Doreau. 1992. Effect of a supply of raw or extruded rapeseeds on digestion in dairy cows. J. Anim. Sci. 70:915-923.

Goetsch, A. L., and M. L. Galyean. 1983. Influence of feeding frequency on passage of fluid and particulate markers in steers fed a concentrate diet. Can. J. Anim. Sci. 63:727-730.

Gonthier, C., A. F. Mustafa, R. Berthiaume, H. V. Petit, R. Martineau, and D. R. Ouellet. 2004. Effects of feeding micronized and extruded flaxseed on ruminal fermentation and nutrient utilization by dairy cows. J. Dairy Sci. 87:1854-1863.

Grainger, R. B., M. C. Bell, J. W. Stroud, and F. H. Baker. 1961. Effect of various cations and corn oil on crude cellulose digestibility by sheep. J. Anim. Sci. 20:319-322.

Hannah, S. M., R. C. Cochran, E. S. Vanzant, and D. L. Harmon. 1991. Influence of protein supplementation on site and extent of digestion, forage intake, and nutrient flow characteristics in steers consuming dormant bluestem-range forage. J. Anim. Sci. 69:2624-2633.

Jenkins, T. C. 1993. Lipid metabolism in the rumen. J. Dairy Sci. 76:3851-3863.

Khorasani, G. R., G. De Boer, P. H. Robinson, and J. J. Kennelly. 1992. Effect of canola fat on ruminal and total tract digestion, plasma hormones, and metabolites in lactating dairy cows. J. Dairy Sci. 75:492-501.

Khorasani, G. R., P. H. Robinson, G. De Boer, and J. J. Kennelly. 1991. Influence of canola fat on yield, fat percentage, fatty acid profile, and nitrogen fractions in Holstein milk. J. Dairy Sci. 74:1904-1911.

Lardy, G. P., and V. L. Anderson. 2009. Alternative feeds for ruminants. Bulletin AS-1182 (revised). North Dakota State University Extension Service, Fargo.

Maddock, T. D., M. L. Bauer, K. B. Koch, V. L. Anderson, R. J. Maddock, G. Barceló-Coblijn, E. J. Murphy, and G. P. Lardy. 2006. Effect of processing flax in beef feedlot diets on performance, carcass characteristics, and trained sensory panel ratings. J. Anim. Sci. 84:1544-1551.

Merchen, N. R. 1988. Digestion, absorption and excretion in ruminants. Pages 172-201 in The Ruminant Animal: Digestive Physiiology and Nutrition. D. C. Church, ed. Waveland Press Inc., Prospect Heights, IL

Moore, J. A., R. S. Swingle, and W. H. Hale. 1986. Effects of whole cottonseed oil or animal fat on digestibility of wheat straw diets by steers. J. Anim. Sci. 63:1267-1273.
Mustafa, A. F., P. Y. Chouinard, and D. A. Christensen. 2003. Effects of feeding micronized flaxseed on yield and composition of milk from Holstein cows. J. Sci. Food Agric. 83:920-926.

Mustafa, A. F., J. J. McKinnon, D. A. Christensen, and T. He. 2002 Effects of micronization of flaxseed on nutrient disappearance in the gastrointestinal tract of steers. Anim. Feed Sci. Technol. 95:123-132.

NRC. 2001. Nutrient Requirements of Dairy Cattle. 7th rev. ed. Natl. Acad. Sci., Washington, DC.

Ørskov, E. R., and I. McDonald. 1979. The estimate of protein degradability in the rumen from incubation measurements weighted according to rate of passage. J. Agric. Sci. (Camb.) 92:499-503.

Palmquist, D. L., and T. C. Jenkins. 1980. Fat in lactation rations: A review. J. Dairy Sci. 63:1-14.

Petit, H. V. 2002. Digestion, milk production, milk composition, and blood composition of dairy cows fed whole flaxseed. J. Dairy Sci. $85: 1482-1490$

Pires, A. V., M. L. Eastridge, J. L. Firkins, and Y. C. Lin. 1997. Effects of heat treatment and physical processing of cottonseed on nutrient digestibility and production performance by lactating cows. J. Dairy Sci. 80:1685-1694.

Reveneau, C. V., D. M. Ribeiro, M. L. Eastridge, N. R. St-Pierre, and J. L. Firkins. 2005. Processing whole cottonseed moderates fatty acid metabolism and improves performance by dairy cows. J. Dairy Sci. 88:4342-4355.

Robertson, J. B., and P. J. Van Soest. 1981. The detergent system of analysis and its application to human foods. Pages 123-158 in The Analysis of Dietary Fiber. W. P. T. James and O. Theander, ed. Marcel Dekker, New York, NY.

Scott, T. A., D. K. Combs, and R. R. Grummer. 1991. Effects of roasting, extrusion, and particle size on the feeding value of soybeans for dairy cows. J. Dairy Sci. 74:2555-2562.

Sullivan, J. L., J. T. Huber, R. L. Price, and J. M. Harper. 1993. Comparison of digestibility, nutritive value, and storage characteristics of different forms of cottonseed in diets fed to lactating dairy cows. J. Anim. Sci. 71:2837-2842.

Tice, E. M., M. L. Eastridge, and J. L. Firkins. 1993. Raw soybeans and roasted soybeans of different particle sizes. 1. Digestibility and utilization by lactating cows. J. Dairy Sci. 76:224-235.

Udén, P., P. E. Colucci, and P. J. Van Soest. 1980. Investigation of chromium, cerium, and cobalt as markers in digesta. J. Sci. Food Agric. 31:625-632.

Vanzant, E. S., R. C. Cochran, and D. E. Johnson. 1991. Pregnancy and lactation in beef heifers grazing tallgrass prairie in the winter: Influence on intake, forage utilization, and grazing behavior. J. Anim. Sci. 69:3027-3038.

Ward, A. T., K. M. Wittenberg, and R. Przybylski. 2002. Bovine milk fatty acid profiles produced by feeding diets containing solin, flax and canola. J. Dairy Sci. 85:1191-1196.

Warner, A. C. I., and B. D. Stacy. 1968. The fate of water in the rumen. 1. A critical appraisal of use of soluble markers. Br. J. Nutr. 22:369-387.

Welch, J. G., and A. P. Hooper. 1993. Ingestion of feed and water. Pages 108-124 in The Ruminant Animal: Digestive Physiology and Nutrition. D. C. Church, ed. Waveland Press Inc., Prospect Heights, IL.

Zinn, R. A., and F. N. Owens. 1986. A rapid procedure for purine measurement and its use for estimating net ruminal protein synthesis. Can. J. Anim. Sci. 66:157-166. 